\title{
A CORRELAÇÃo dA ESTRUTURA GEOMÉTRICA E O SigNificAdo Bíblico-TEOLÓgICo NAS OBRAS dA SANTíSSIMA Trindade de ANDREJ RUBLËV E ClÁudio PASTRO
}

\author{
THE CORRELATION OF THE GEOMETRY \\ AND BIbLICAL-THEOLOGICAL MEANING IN THE HoLY TRINITY'S PIECES BY \\ ANDREJ RUBLËV AND CLÁUDIO PASTRO
}

\author{
Hilda Souto * \\ Márcio Luiz Fernandes ${ }^{* *}$
}

\begin{abstract}
RESUMO
As estruturas geométricas implícitas nas pinturas dos tradicionais ícones bizantinos trazem não apenas uma lógica formal, mas também uma simbologia que corresponde à teologia da obra. Tais estruturas são responsáveis pela harmonia e pelo equilíbrio de todo o conjunto. Em uma análise comparativa entre as pinturas da Santíssima Trindade, de Andrej Rublëv (1360-1430) ${ }^{1}$ e de Cláudio Pastro (1948-2016) ${ }^{2}$, dois artistas relevantes para a história da arte sacra oriental e ocidental, respectivamente, verifica-se a importância dessa geometria como estrutura fundante da composição da obra e de grande auxílio para a compreensão teológica do tema. A partir de um diálogo com teólogos dos séculos XX e XXI, constata-se a insuficiência da linguagem humana para transmitir o mistério Trinitário em imagens. Artistas de distintas épocas pintaram obras com o objetivo de retratar o tema, cuja complexidade é assinalada em literatura de grandes teólogos. Tendo esse pano de fundo, observa-se na análise iconográfica e iconológica da pintura de Rublëv e de Pastro como a maneira de retratar a Trindade por estes dois artistas está embasada na tradição e no magistério das Igrejas Ortodoxa e Católica. A análise estrutural geométrica não pretende reduzir o tema a linhas ou figuras bidimensionais, mas, pelo contrário, quer demonstrar que essas estruturas têm uma razão de ser e auxiliam na compreensão teológica e na leitura da obra.
\end{abstract}

Palavras-chave: Trindade. Imagem. Iconografia. Andrei Rublëv. Cláudio Pastro.

\section{ABSTRACT}

The geometrical structures within the paintings of traditional byzantine icons bring not only a formal logic, but also a symbology that corresponds to the piece's theology. These structures are responsible for the entirety's harmony and balance. In a comparative analysis between the Hole Trinity paintings by Andrej Rüblev (1360-1430) and Cláudio Pastro (1948-2016), two relevant

\footnotetext{
* Mestre em Artes Visuais pela Universidade Estadual Paulista Júlio de Mesquita Filho - UNESP, Doutoranda em Teologia pela PUC do Paraná, e graduada em Licenciatura em Artes Plásticas pela Fundação Armando Álvares Penteado - FAAP. Brasil. ORCID: 0000-0001-6101-8800. E-mail: hildasouto.arte@gmail.com.

** Doutor em Psicologia pela Universidade de São Paulo, mestre em Teologia Fundamental pela Pontifícia Universidade Lateranense e pós-doutor em Psicologia pela Universidade de São Paulo. Professor adjunto no Programa de Pós-Graduação em teologia da PUC do Paraná e da Faculdade Claretiana Studium Theologicum. ORCID: 0000-0002-0944-1676. Email: marcio.luiz@pucpr.br.

${ }^{1}$ Monge russo, é considerado um dos maiores pintores de ícones. Não se tem muitas informações a respeito de sua vida privada, nem da data de nascimento e morte. Foi canonizado em 1988.

2 Paulistano, nascido em 15 de outubro de 1948, dedicou-se exclusivamente à arte sacra por 40 anos.
} 
artists to the oriental and occidental sacred art's history, respectively, it is possible to verify the importance of this geometrical aspect as a base to the piece's composition and great support to the theme's theological comprehension. From a dialogue with theologians from the XXI and XX centuries, it is possible to verify the human language's insufficiency to transmit the Holy Trinity's mystery in images. Artists from distinct periods painted as to portray the complexity within the theme which is marked in great theologians' literature. With this background in mind, it is possible to observe in the iconographic and iconological analysis of Rüblev's and Pastro's paintings how Trinity's representation by these two artists is based on the tradition and mystery of the Orthodoxal and Catholic Churches. The structural and geometrical analysis does not intend to reduce the theme to lines or bi-dimensional figures, but the opposite. It intends to show that these structures have a reason and help in the theological comprehension and description of the piece.

Key words: Trinity. Image. Iconography. Andrei Rublëv. Cláudio Pastro.

\section{INTRODUÇÃO}

A análise das estruturas geométricas que fundamentam as pinturas dos ícones é um estudo relevante na área da iconografia. Tais estruturas são a base do desenho para o iconógrafo e é na tradição dos ícones bizantinos que ficam mais evidentes. Na pintura da Santíssima Trindade de Andrej Rublëv, a geometria implícita, cujo estudo já é notório, além da harmonia e equilíbrio que proporciona, traduz o significado bíblico-teológico da obra. Para um artista sacro contemporâneo, fruto do Concílio Ecumênico Vaticano II3, como Cláudio Pastro, cuja fonte de conhecimento da arte sacra acontece no encontro com a arte românica e bizantina, essas estruturas não são pré-requisito para a composição da obra. Entende-se, todavia, que a partir do momento em que o artista sofre a influência da pintura do ícone, suas composições estão alicerçadas nesse planejamento mesmo que tenha uma linha de desenho mais espontânea, seguindo por consequência o que a simbologia iconográfica aponta como essencial. É um ritmo distinto que lança mão da tradição simbólica, mas que emerge não só da habilidade manual do artista, mas da relação entre vida, espiritualidade e a tradição da arte sacra oriental.

A presente reflexão, fundamentada na bibliografia existente a respeito de iconografia bizantina e em fontes teológicas que aprofundam, especificamente, o tema do mistério do Deus Uno e Trino, quer estabelecer mais enfaticamente pontos de congruência entre essas duas áreas de conhecimento e estabelecer critérios que auxiliem na compreensão e no

3 O Concílio Ecumênico Vaticano II foi consagrado o maior evento católico do século XX. Convocado pelo Papa João XXIII e aberto oficialmente em 11 de outubro de 1962, foi encerrado pelo Papa Paulo VI em 8 de dezembro de 1965. Foram quatro anos de grandes reflexões em que se plasmou o principal objetivo do Concílio: a renovação da Igreja, ou seja, segundo o Papa João XXIII, um Novo Pentecostes. Um dos principais pontos de atualização deu-se na liturgia, que passou a ser celebrada de frente para o povo, tornando-se assim uma celebração comunitária, cujo centro é o próprio Cristo. Além disso, retornar ‘as fontes foi redescobrir as riquezas espirituais, doutrinárias e litúrgicas do primeiro milênio do cristianismo, sobretudo na arte sacra. 
diálogo enriquecedor entre a arte e a teologia. Esse artigo leva em conta que há uma profusa e relevante discussão no estudo da Trindade tanto na Igreja Ortodoxa Russa quanto na Católica Apostólica Romana, das quais foram membros Rublëv e Pastro, respectivamente.

A análise comparativa que se pode estabelecer entre a forma, o conteúdo e o esquema composicional das obras, reconhecendo aspectos que se assemelham e outros que diferem, são levantados a partir da observação e de uma leitura iconográfica das pinturas.

Por que Andrei Rublëv? Por que Cláudio Pastro?

Rublëv e Pastro eram homens de fé, dedicados à arte sacra e fiéis ao Magistério das Igrejas Ortodoxa Russa e Católica Apostólica Romana, respectivamente. Partindo de uma profunda espiritualidade, colocaram suas obras a serviço da Igreja. O primeiro foi canonizado em 1988, segundo a tradição da Igreja Ortodoxa. Seus ícones, aos quais foram atribuídos milagres, tornaram-se objetos de veneração do povo russo. A Santíssima Trindade de Rublëv, pintada por volta de 1411, é um dos ícones emblemáticos da tradição bizantina e, segundo Evdokimov (apud DONADEO, 1996, p. 118), “[...] não existe algures nada semelhante quanto à força de síntese teológica, à riqueza do simbolismo e à beleza artística".

A história de vida de Pastro, e sua profícua obra, é recente. Foi um artista dedicado exclusivamente à arte sacra por 40 anos. Seus trabalhos podem ser vistos em muitas igrejas e capelas espalhadas pelo Brasil, Itália, Alemanha, França e Espanha. No final da década de 1990, foi convidado a criar o projeto iconográfico no interior do Santuário Nacional de Nossa Senhora Aparecida, estado de São Paulo, sua obra mais importante. Percebe-se, claramente, que sua trajetória artística é o entrelaçamento de sua arte com a alma brasileira, tendo declarado que os "[...] os anônimos, índios e negros, com suas milenares artes" (PASTRO, 2001, p.19) eram-lhes muito caros. Para o Concílio Ecumênico Vaticano II, "a arte deve ser livremente exercida na Igreja, segundo as tendências dos nossos tempos, de todos os povos e de todas as regiões" (SC n. 123)4.

Por pouco, Pastro não foi monge, mas em 17 de outubro de 2004 tornou-se oblato 5 beneditino da Abadia Nossa Senhora da Paz, em Itapecerica da Serra, SP, onde está sepultado. Aquele foi o lugar que escolheu para o repouso de seu corpo.

\footnotetext{
4 SC = CONCÍLIO VATICANO II. Constituição sobre a Sagrada Liturgia Sacrosanctum Concilium. $11^{\mathrm{a}}$ ed. São Paulo: Edições Paulinas, 2011.

5 "O Oblato beneditino é já um cristão que, impulsionado pelo desejo de levar uma vida mais perfeitamente de acordo com o ideal do Evangelho, filia-se a uma família monástica de sua escolha, por um laço de ordem espiritual, a fim de poder, graças a esta filiação, participar dos bens espirituais desta comunidade, buscado nesta comunhão vital, um acréscimo de fervor e de generosidade no serviço de Deus". (MOSTEIRO DE SÃO BENTO DO RIO DE JANEIRO, s/d).
} 
Pastro realizou várias obras com o tema da Trindade e elas seguem, em sua maioria, a representação da tradição bizantina: a história da hospitalidade de Abraão.

A pintura escolhida para fazer o contraponto com a de Rublëv está na Casa de Retiros das Andrelinas, em Rondinha, Paraná, Brasil, executada em 2008. Trata-se de uma obra que une o bidimensional da pintura mural com a tridimensionalidade do espaço da capela onde está colocada, preocupação constante do artista que, além de pintor, dedicava-se a reformas e adaptações do espaço litúrgico segundo os ditames do Concílio Ecumênico Vaticano II.

A interface teológica como contribuição para uma discussão teórica, ampliando o grau de entendimento do tema, foi realizada a partir de fontes de pesquisa bibliográficas com Jürgen Werbick em Doutrina da Trindade (2001); Lubomir Žak em A Trindade como mistério central da fé cristã (2012); Maria Clara Lucchetti Bingemer e Vitor Galdino Feller em A aventura de pensar e falar sobre o Deus de nossa fé (2003) e Jean-Noël Bezançon em Representar a Trindade? (2003).

Elaborou-se a análise formal recorrendo a Egon Sendler, Saverio Licari e Erwin Panofsky, colocando em discussão a relação entre forma e conteúdo, iconografia e iconologia.

\section{A RESPEITO DA DOUTRINA DA TRINDADE}

Dada a importância da doutrina da Trindade como fonte primordial da fé no âmbito das igrejas Ortodoxa e Católica, destacam-se aqui as reflexões que Losskij, Bingemer e Feller fazem a respeito do tema.

Para Losskij (apud ŽAK, 2012, p. 65), "a Trindade é o dogma central da ortodoxia" e é nela e para ela que tudo se volta e se afirma. Bingemer e Feller (2003, p. 13) afirmam que "o Cristianismo, a fé cristã e a linguagem cristã estão sempre permeados e penetrados pela revelação trinitária de Deus". Suas reflexões sobre o significado do mistério da Trindade para os cristãos são fundamentadas a partir do Catecismo da Igreja Católica (n. 234):

O mistério da Santíssima Trindade é o mistério central da nossa fé e da vida cristã. É o mistério de Deus em si mesmo. É, portanto, a fonte de todos os outros mistérios da fé, é a luz que os ilumina [...]. Toda a história da salvação não é senão a história da via e dos meios pelos quais o Deus verdadeiro e único, Pai, Filho e Espírito Santo, se revela [...]. (CIgC n. 234).

Porém, esses autores colocam perguntas a respeito de como comunicar esse mistério central da fé cristã ao ser humano contemporâneo: como falar de Deus hoje? "Como, com 
que direito, nos propomos a falar de Deus? A tentativa de falar de Deus é possível? Isso é possível hoje?” (BINGEMER e FELLER, 2003, p. 13). E acrescenta-se a indagação: é possível representar o sagrado hoje?

Bingemer e Feller (2003, p. 14) propõem uma metodologia baseada na teologia católica, com o objetivo de "encontrar palavras novas e inteligíveis para dizer esta mesma verdade que está no coração de nossa vida: Cremos em Deus uno e trino”. Os autores indicam requisitos favoráveis e necessários, como um pano de fundo, para nos aproximarmos do conhecimento do Deus revelado em Jesus Cristo, do convite que parte Dele mesmo para conhecê-Lo e onde a comunhão entre os crentes se dá de maneira explícita. Os passos para esse conhecimento baseiam-se na tradição da Igreja Católica Romana, na vida das primeiras comunidades cristãs (passado); nas circunstâncias atuais em que vivem os cristãos em suas comunidades, com suas necessidades básicas (presente) e na esperança da ressurreição que o ser humano é convidado a viver (futuro).

O primeiro passo é “[...] refazer o itinerário dos primeiros séculos da história da Igreja” (BINGEMER e FELLER, 2003, p. 14), das primeiras comunidades cristãs que nos transmitiram a fé e nos narraram a Trindade proclamando o evento pascal por meio das antigas confissões de fé.

O segundo é o de saber ouvir as comunidades eclesiais emergentes, cuja experiência é única e irrepetível. No seio dessas comunidades brotam as experiências vivas de cada época e de cada lugar, a seu modo e segundo suas tradições culturais.

O terceiro é caminhar juntos àqueles que fazem, hoje, uma experiência de acreditar e amar a Deus acima de todas as coisas e de qualquer desesperança. Com relação a esse terceiro ponto da metodologia, o teólogo alemão Werbick (2001, p. 509) ressalta:

Deus escolheu a comunhão dos crentes para retratar o mistério da tri-unidade divina na História, a fim de que a história da humanidade seja percebida sempre mais e com nitidez crescente como o caminho para a communio escatológica dos irmãos e das irmãs de Jesus com seu Pai divino no Espírito Santo. (WERBICK, 2001, p. 509).

A história do cristianismo é história de revelação. Conhecemos Deus por Ele mesmo falar de si e revelar-se como Trindade: Pai, Filho e Espírito Santo na Bíblia, nas Igrejas de confissão cristã e na experiência pessoal de cada um e dos outros com os quais comungamos na fé. O evento trinitário pascal tem, portanto, incidência na vida pessoal e comunitária. Assim, “[...] o mistério proclamado se torna mistério celebrado, para ser na Igreja e na história mistério vivido" (FORTE, 1987, p. 59). 
Deus é Pai, afirma o Novo testamento, e, nesse sentido, é preciso dar um passo além da experiência do povo de Israel, que reconhecia Deus como ser superior e inacessível, para reconhecê-lo na perspectiva de que Ele também é Filho. Em Jesus a revelação se completou, vislumbramos o Seu rosto. Vendo-O, vemos o Pai. Tal acontecimento histórico traz uma nova maneira de Deus se comunicar com seu povo. Deus é Espírito Santo, pois é Ele que nos conduz ao Pai e ao Filho. Ele opera, naqueles que se abrem à sua ação, o mover-se e viver em Deus e em Jesus. Nessa comunhão nasce a inteireza do ser e não exclui nenhuma condição humana, mas, pelo contrário, as reúne em conformidade com a liberdade do indivíduo e a operacionalização do Espírito. Em nome do Pai e do Filho age o Espírito, na comunhão das três pessoas, e esse relacionamento de gratuidade funda uma outra maneira de viver, diferente da lógica de um mundo onde Deus não conta.

A Doutrina da Trindade é uma doutrina que comunica o Ser de Deus, partindo d'Ele mesmo, na comunhão de amor, na correspondência ao sofrimento do coração humano e, principalmente, na esperança da ressurreição.

Para Werbick (2001, p. 430), a relação pericorética ${ }^{6}$ entre as três pessoas da Santíssima Trindade é uma realidade "[...] além da qual o ser humano não é capaz de pensar algo maior ou mais perfeito [...]" e sublinha como sendo o maior exemplo de comunhão a ser seguido.

Para o ser humano contemporâneo, que vive em constantes dúvidas, rixas e sofre violências de todo tipo, a proposta de vida em comunhão como a da Trindade parece utópica? Uma sociedade em que a partilha e a concórdia deveriam existir parece não ter mais lugar para se desenvolver?

\subsection{A dificuldade de traduzir Trindade em palavras}

Não é desconhecida a antiga discussão e discordância a respeito da representação iconográfica de Deus, de Nossa Senhora e de seus santos. Em Êxodo $\left(\operatorname{Ex}^{7} 20\right)^{8}$, o texto é claro em afirmar que a execução de imagens e sua veneração não se presta ao culto do Deus único e verdadeiro. Por sua vez, na tradição judaico-cristã é clara a consciência dessa

\footnotetext{
${ }^{6}$ Pericórese: termo aplicado à teologia trinitária pelos Padres da Igreja, sobretudo Gregório de Nazianzeno, Gregório de Nissa e João Damasceno. "[...] pericorese trinitária entende-se pela mútua compenetração e inabitação das três Pessoas Divinas entre si. As Pessoas Divinas, em sentido pericorético, formam por si mesmas sua unidade no círculo eterno da vida divina e do amor recíproco e relacional de cada uma das Pessoas da Trindade, uma pela outra, e também para o desenvolvimento na relação entre Deus e o homem, da comunhão eclesial e social”. (MEIRA, 2017, p. 39).

7 Todas as citações bíblicas do texto têm como referência a BÍBLIA DE JERUSALÉM, 1981.

8 BÍBLIA DE JERUSALÉM (Ex 20, 4): "Não farás para ti imagem de escultura, nem semelhança alguma do que há em cima, nos céus, nem embaixo, na terra, nem nas águas debaixo da terra”.
} 
inacessibilidade à substância de Deus e a incapacidade da linguagem humana para poder exprimi-la.

O movimento iconoclasta, ou seja, a grande discussão em torno das imagens e sua proibição, foi desencadeado em 725 pelo imperador Leão III, no Império Bizantino. Os séculos VIII e IX foram palco da acirrada luta dos que eram a favor das imagens e daqueles que enxergavam na prática da veneração apenas a idolatria. Além de questões dogmáticas, "práticas supersticiosas e idolatrias a respeito das imagens sacras agravaram a oposição destas tendências. Fatores de ordem política contribuíram também com o conflito [...]" (SENDLER, 1995, p. 26, tradução nossa)9.

Em 787, foi convocado o II Concílio de Niceia (VII Concílio Ecumênico), pela imperatriz Irene, o qual congregou 367 padres vindos de todo o Oriente e representantes do Ocidente. A Igreja una, do primeiro milênio legitimou a representação iconográfica para veneração de Cristo, de Nossa Senhora e dos santos, porém omitiu questões relativas à Santíssima Trindade (MEIER, 2019, p. 176). As diretrizes fundamentais que diziam respeito à "[...] humanidade e divindade de Cristo, a essência da Trindade e a relação de Maria com Jesus enquanto Deus e enquanto ser humano" (BELLITTO, 2010, p. 31) foram tratadas em concílios anteriores: em Niceia I (325) e Constantinopla I (381).

Convocado por Constantino ${ }^{10}$, o I Concílio de Niceia se opôs à teologia de Ário (260335), um sacerdote norte-africano. Seu principal argumento era que Jesus não era completamente divino e que Ele "[...] e seu Pai não eram coeternos [, concluindo-se] que Jesus havia sido criado pelo Pai e, portanto, teria de ser inferior a Deus” (BELLITTO, 2010, p. 35). A resposta do Concilio de Niceia à heresia ariana foi a profissão de fé “[...] precisando a geração eterna do Verbo pelo Pai e sua consubstancialidade com Ele [...]” (MONDONI, 2014, p. 138). "O Concílio acabou empregando a palavra homoousios para definir o fato de que Jesus e seu Pai eram 'um no ser', ou 'do mesmo ser' ou 'da mesma substância” (BELLITTO, 2010, p. 35). No Concílio de Constantinopla, os bispos “[...] confirmaram o símbolo niceno e aceitaram os acréscimos relativos ao Espírito Santo: Senhor e vivificador, que procede do Pai, junto com o Pai e o Filho é adorado e glorificado, e falou pelos profetas" (MONDONI, 2014, p. 151).

Impasses teológicos, além do ariano, adentraram a história dos Concílios do primeiro

\footnotetext{
${ }_{9}$ Pratiche superstiziose, idolatriche nei riguardi delle immagini sacre, aggravavano l'opposizione di queste tendenze. Fatti di ordine politico contribuirono anch'essi al conflitto [...].(SENDLER, 1995, p. 26).

10 O Imperador Constantino (272-337), que governou de 306 a 337, proibiu a perseguição aos cristãos. Transferiu a capital do Império Romano para Bizâncio rebatizando a cidade de Constantinopla, hoje Istambul.
} 
milênio levantando questões que abalaram tanto a Igreja do Ocidente quanto a do Oriente. Além do grupo que negava a divindade de Jesus, também havia outro que negava a divindade do Espírito Santo e outro mais, liderado por Nestório, bispo de Constantinopla, que "[...] sustentava que Maria era mãe do ser humano Jesus, mas não era a mãe de Deus" (BELLITTO, 2010, p. 39). No Concílio de Éfeso, em 431, confirmaram-se as duas naturezas, humana e divina de Jesus, e os bispos reconheceram Maria como a Theotokos, a Mãe de Deus.

\subsection{A dificuldade de traduzir Trindade em imagem}

A respeito da dificuldade de conceber uma imagem adequada para a representação de Deus, e sobretudo da Trindade, Werbick (2001, p. 429) cita a condenação do Papa Urbano VIII, em 1628, àqueles que desejavam representá-la. O mesmo pontífice repudiou também as representações das trindades '[...] 'tricéfalas' [Imagem 1] e ordenou que se queimassem tais monstruosidades" (BEZANÇON, 2003, p. 133). O que se considera com grande cuidado aqui é o fato de que é impossível pintar a Santíssima Trindade, mas se pode tentar traduzir a Trindade em imagem e, desse modo, chegar a escrever um ícone no qual o Deus Uno e Trino entra em comunhão com o ser humano.

Em 1745, foi a vez do Papa Bento XIV se posicionar em relação às representações da Trindade. Segundo Bezançon (2003, p. 133), na carta dirigida ao bispo de Augsburgo, Sollicitudini nostrae, o pontífice "[...] investe contra outras aberrações, como estatuetas muito difundidas nos Países Baixos “nas quais Maria, 'Mãe de Deus', [...] é representada não só como mãe de Jesus que é Deus, mas como mãe da Trindade” (Imagem 2).
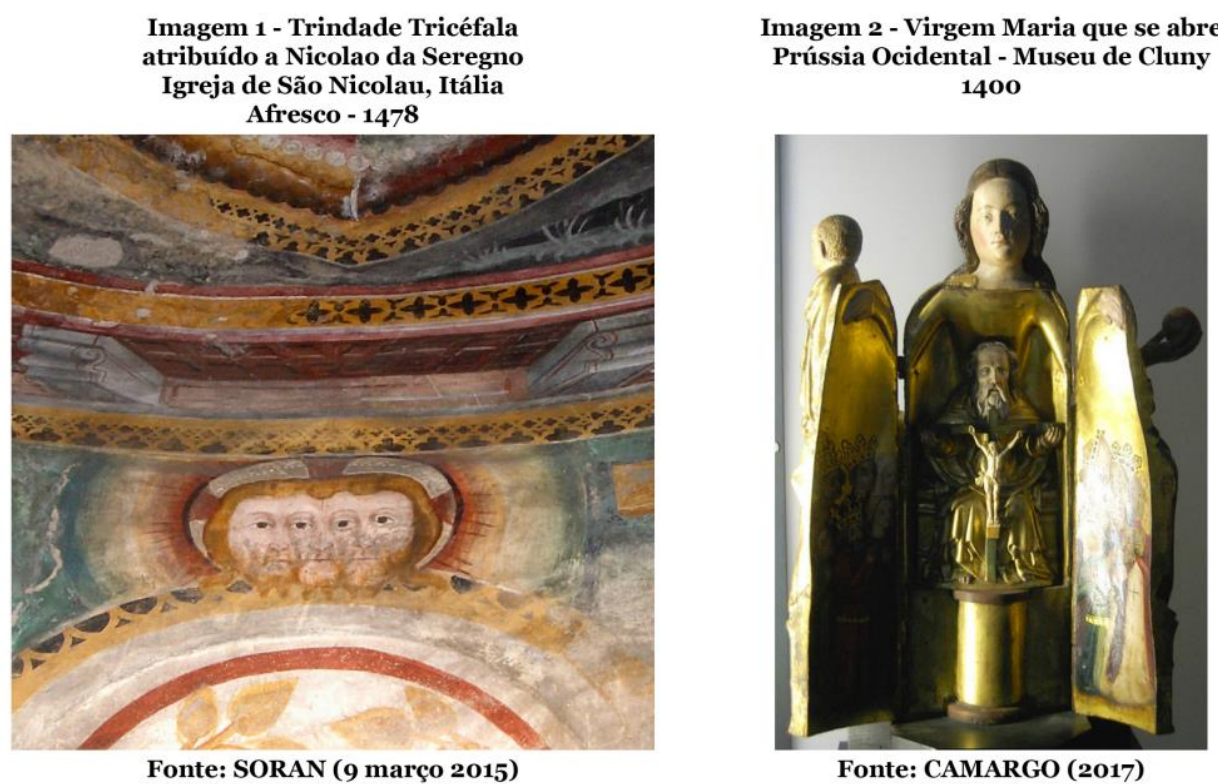

Fonte: CAMARGO (2017) 
Losskij (apud ŽAK, 2012) fala sobre o limite da linguagem humana em dar uma definição significativa da Santíssima Trindade, sendo que a expressão humana sobre qualquer questão relacionada a Deus é insuficiente. Há representações (Imagens 3 e 4) que nos falam de uma Trindade cuja hierarquia entre as três pessoas parece existir. Para esse tipo de representação o Grande Sínodo de Moscou, de 1667, declara:

É absurdo e impróprio pintar em ícones a Deus Pai com barba cinza e o Filho Unigênito em seu seio com uma pomba entre ambos, posto que ninguém viu o Pai segundo a Sua Divindade, que o Pai não tem carne [...] e que o Espírito Santo não é, em essência, uma pomba, mas, em essência, Deus. (GRANDE SÍNODO DE MOSCOU, 1667).
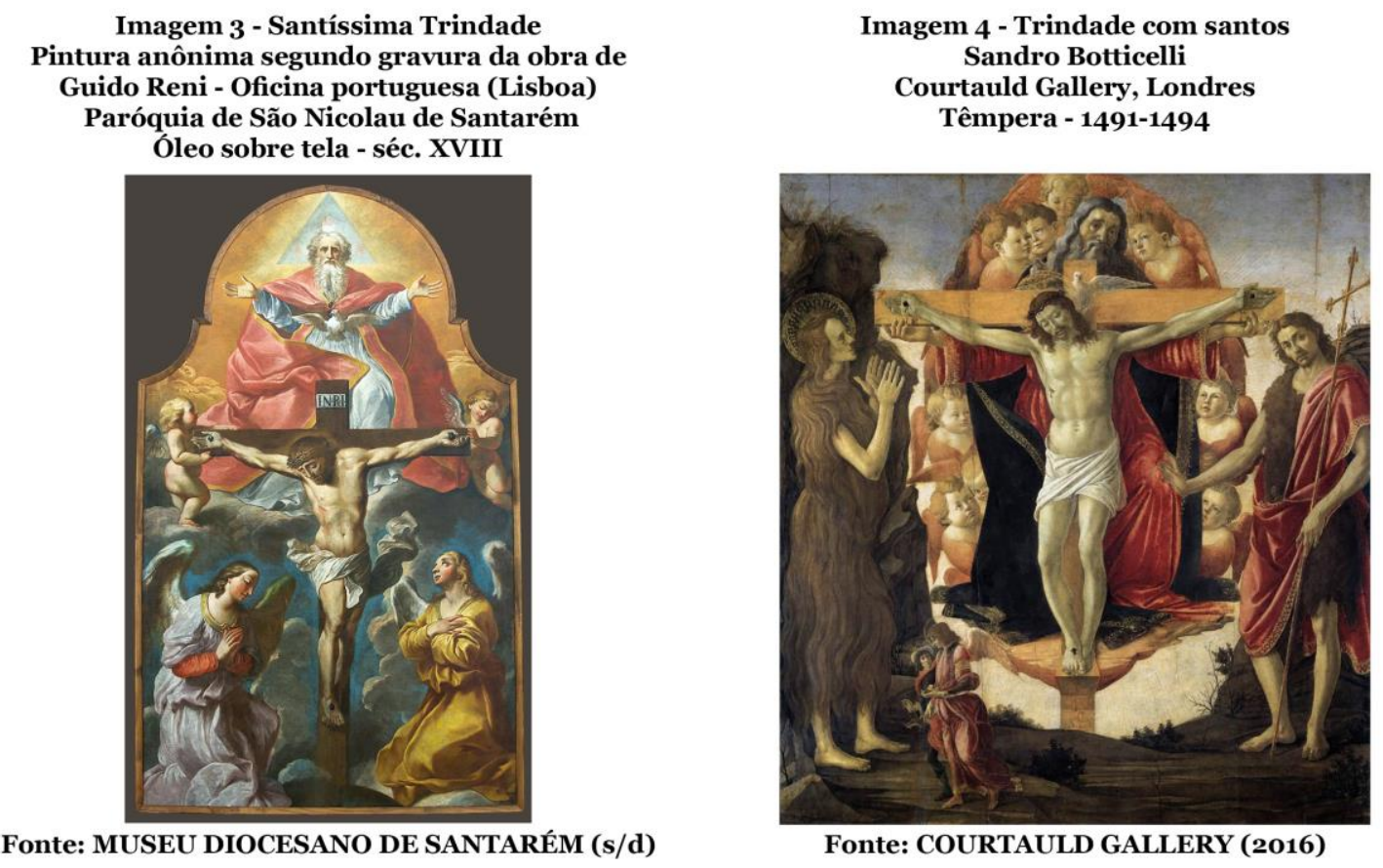

Fonte: COURTAULD GALLERY (2016)

Após tantas controvérsias, devemos nos perguntar a respeito das fontes que inspiraram Rublëv e Pastro na representação da Trindade. Serão apenas fruto de suas inspirações individuais ou podemos verificar os fundamentos na tradição ortodoxa e católica?

Segundo Boespflug (apud MEIER, 2019, p. 297):

[...] a ideia de um colóquio da Trindade Santa, a fim de salvar o mundo, é conhecida desde Irineu de Lyon e está baseada na Patrística, em Santo Ambrósio e Santo Agostinho. Fica-se sabendo, desta forma, que Deus tem planos e que os debates resultarão na estratégia de sua intervenção neste mundo: o Espírito Santo será enviado para dar vida e o Filho virá para vencer o mal e a morte, salvando a todos, inclusive os que faleceram antes de sua vinda. (BOESPFLUG apud MEIER, 2019, p. 279). 
Outra justificativa para a representação do tema está “[...] no famoso tema bíblico do Gênesis que descreve a visita dos três anjos a Abrãao, no carvalho de Mambré (Gn 18, 1-16). É a famosa Filoxénia (hospitalidade, em grego) de Abrãao [...] (LICARI, 2013, p. 58).

As representações da Santíssima Trindade ao longo da história receberam diversas possibilidades de narrativas e, consequentemente, de leituras possíveis para sua interpretação, mas, segundo Sendler (1985, p.63), a imagem na iconografia bizantina tem uma justificativa e uma razão de ser:

[...] apesar das erudições e do interesse dos bizantinos pela ciência, a questão da semelhança com a natureza não apareceu, porque a imagem devia representar a verdade eterna. Para exprimir seu caráter misterioso, tinha que se servir de uma linguagem também misteriosa, diferente daquela do nosso mundo. (SENDLER, 1985, p. 63, tradução nossa) ${ }^{11}$.

A maneira como estão representadas as três pessoas nas obras de Rublëv e de Pastro, nos comunica a dimensão da reflexão teológica que esse tema traz? O que essas imagens nos oferecem quanto à compreensão da Trindade? Uma pintura pode traduzir em traços e cores a partilha, a unidade e a perfeita comunhão entre as três pessoas?

O ícone é a Palavra pintada. Trata-se de um texto imagem que quer comunicar a fé. Assim, o ícone é um símbolo que provoca o pensamento e tem de ser estudado com a mesma sensibilidade e inteligência interpretativa com que nos aproximamos da Sagrada Escritura. O iconógrafo encontra nas Sagradas Escrituras sua inesgotável fonte de inspiração. Diante disso, afirma Bezançon (2003, p. 134):

Nas múltiplas controvérsias que surgiram sem cessar em torno desse problema delicado da representação legítima da Trindade, parece claro que o princípio fundamental, tanto no Oriente como no Ocidente, seja a fidelidade às Escrituras. Deus só pode ser representado sob a forma segundo a qual ele mesmo se manifestou. (BEZANÇON, 2003, p. 134).

Por outro lado, vale recordar que ao lado desse núcleo bíblico que fundamenta o ícone, temos também o núcleo fortemente presente da Tradição. O ícone se tornou, conforme salientam Šplidlík e Rupinik (2000, p. 12) “[...] por meio dos sínodos e concílios parte da linguagem ortodoxa eclesial universal [...]”, principalmente pela sua potente relação com a oração e a liturgia mais do que por considerações doutrinais e artísticas presentes.

${ }^{11}$ [...] malgrado l'erudizione e l'interesse dei bizantini per le scienze, la questione della somiglianza con la natura non si poneva, perché lïmmagine doveva rappresentare le verità eterne. Per esprimere il loro carattere misterioso, doveva servirsi di un linguaggio pure misterioso, diverso da quello del nostro mondo. (SENDLER, 1985, p. 63). 
Outra fonte em que Rublëv e Pastro se basearam para pintar os rostos dos anjos é perícope em que Filipe pede: "Senhor, mostra-nos o Pai, o que nos basta. E disse-lhe Jesus: Estou há tanto tempo convosco, e não me conheces, Filipe? Quem me vê, vê o Pai” (Jo 14, 89). E para o Espírito Santo, a promessa de Jesus: "E eu rogarei ao Pai, e ele vos dará outro Consolador, para que fique convosco para sempre” (Jo 14, 16). O Filho e o Espírito Santo são os dois Consoladores, a mesma face da misericórdia do Pai.

\subsection{Rublëv e a tradição iconográfica da Trindade}

Andrei Rublëv foi um monge russo que, sob a forte e profunda espiritualidade de São Sergio de Radonez (1314-1392), pintou o ícone da Santíssima Trindade por volta de 1411. Considerado o São Bento do Oriente, São Sergio reuniu - em torno do Mosteiro que fundou dedicado à Santíssima Trindade -, um povo sofrido e angustiado por causa das invasões dos tártaros que deixaram muita miséria e destruição ao povo russo. O país estava devastado pelas invasões e Sérgio, “[...] doce e pobre [...] mergulha mais no mistério dos Três do que na densa floresta de Radonez” onde foi eremita (ANGE, 2014, p. 12, tradução nossa) ${ }^{12}$.

Ao redor do seu Mosteiro nasceram comunidades que admiravam seu modo de viver e queriam participar da mesma experiência. No espaço de 150 anos, as fundações de São Sérgio somavam 180 novos mosteiros. O objeto de sua contemplação foi a Trindade. Evdokimov (1971, p. 281 apud PASSARELLI, 1996, p. 15) escreveu sobre o monge:

Pode-se dizer que São Sérgio reuniu a Rússia de seu tempo em torno de sua igreja, em torno do nome de Deus, para que os homens, 'mediante a contemplação da Trindade, vençam a odiosa divisão do mundo’. (EVDOKIMOV, 1971, p. 281 apud PASSARELLI, 1996, p. 15).

São Sérgio teve como sucessor o abade de nome Nikon. A seu pedido, Rublëv pintou o ícone da Trindade. A pintura está exposta atualmente na Galeria Tretyakov, em Moscou. Rublëv certamente presenciou a destruição e a dor do povo russo, assolado por tantas invasões e mortes, mas, na prática de intensa oração e jejum, concebeu a representação da Trindade que conhecemos hoje em dia.

Florenskij (1977) refere-se ao ícone de Rublëv como uma obra inspirada e que segue a tradição de outras com o mesmo tema. Um exemplo é o mosaico da Igreja de Santa Maria Maggiore, Abraão e os Anjos, em Roma, que data do século V (Imagem 5).

Na cena do mosaico, na metade superior, Abrãao corre em direção aos três visitantes

\footnotetext{
${ }_{12}$ [...] dolce e povero [...] si immerge più nel mistero dei Tre che nella fitta selva di Radonez. (ANGE, 2014, p. 12).
} 
e, logo abaixo, prepara a refeição com a ajuda de Sara seguindo, mais uma vez, a perícope atribuída a Gênesis 18, 6: "Abraão apressou-se para a tenda, junto a Sara e disse: 'Toma depressa três medidas de farinha, de flor de farinha, amassa-as e faze pães cozidos"' (Gn 18, 6). Špidlík e Rupnik (2000, p. 24) relatam que a visita destes três anjos representa a vida, a comunhão, enquanto os dois personagens, Sara e Abraão, mostram a esterilidade e a impotência humana para dar a vida.

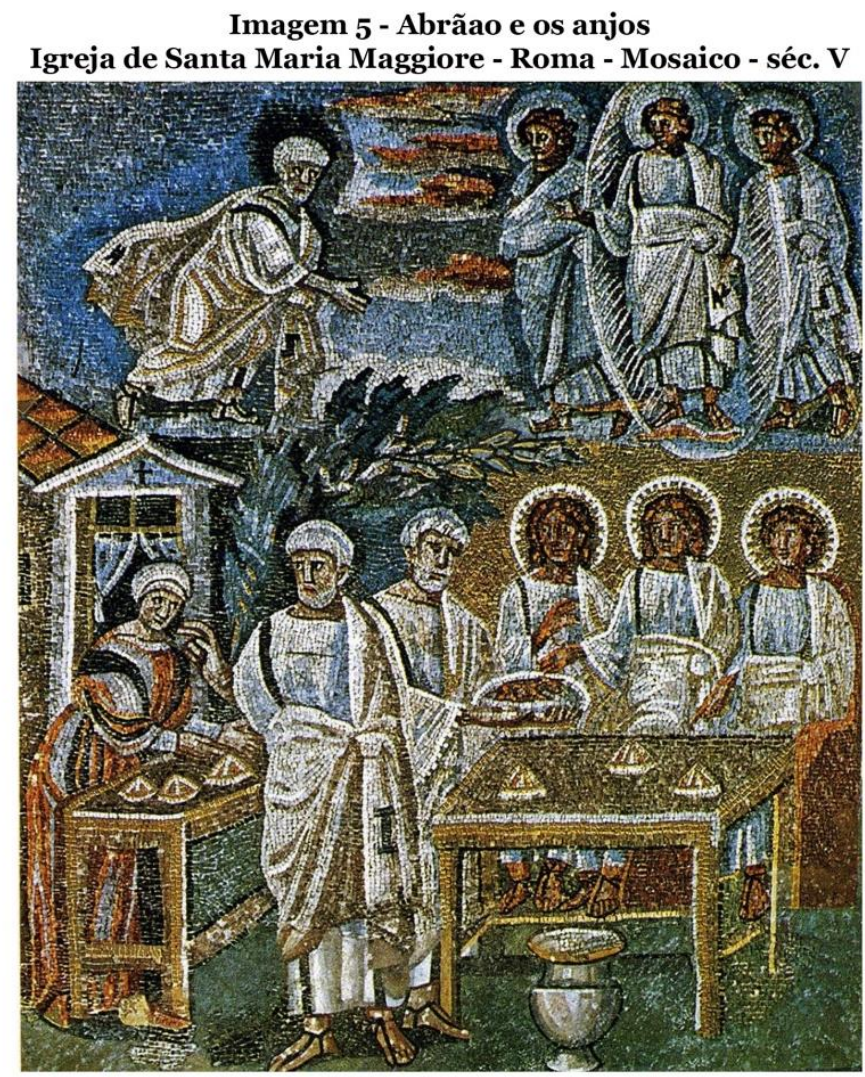

Fonte: SORAN (9 março 2015)

Outro exemplo de representação da mesma temática é a do filósofo e iconógrafo Teófanes, o Grego (1340 - 1410), que pintou a cena da Trindade (Imagem 6), em 1378, na Igreja da Transfiguração, em Novgorod, lugar onde vigorou uma das principais escolas de iconografia da Rússia. Em 1405, com dois de seus discípulos, Prokhor de Gorodets e o monge Andrej Rublëv, afrescou a catedral da Anunciação, no Kremlin.

Na pintura, pode-se notar a representação dos três anjos sentados à mesa. Sara, que está no quadrante inferior direito, serve os visitantes. Falta Abrãao, cuja figura estaria, segundo Russak (ICONE, 1982, p. 14) no quadrante inferior esquerdo onde a pintura sofreu uma perda pictórica considerável. "Toda a composição está contida em um triângulo, na parte superior, os três Anjos, sentados à mesa, formam um círculo. Os Anjos têm nas mãos um bastão, enquanto o do centro segura também um pergaminho; este detalhe é típico da 
representação do Cristo Emanuel” (ICONE, 1982, p. 14, tradução nossa) ${ }^{13}$. O centro do círculo coincide com a posição do cálice sob a mesa.

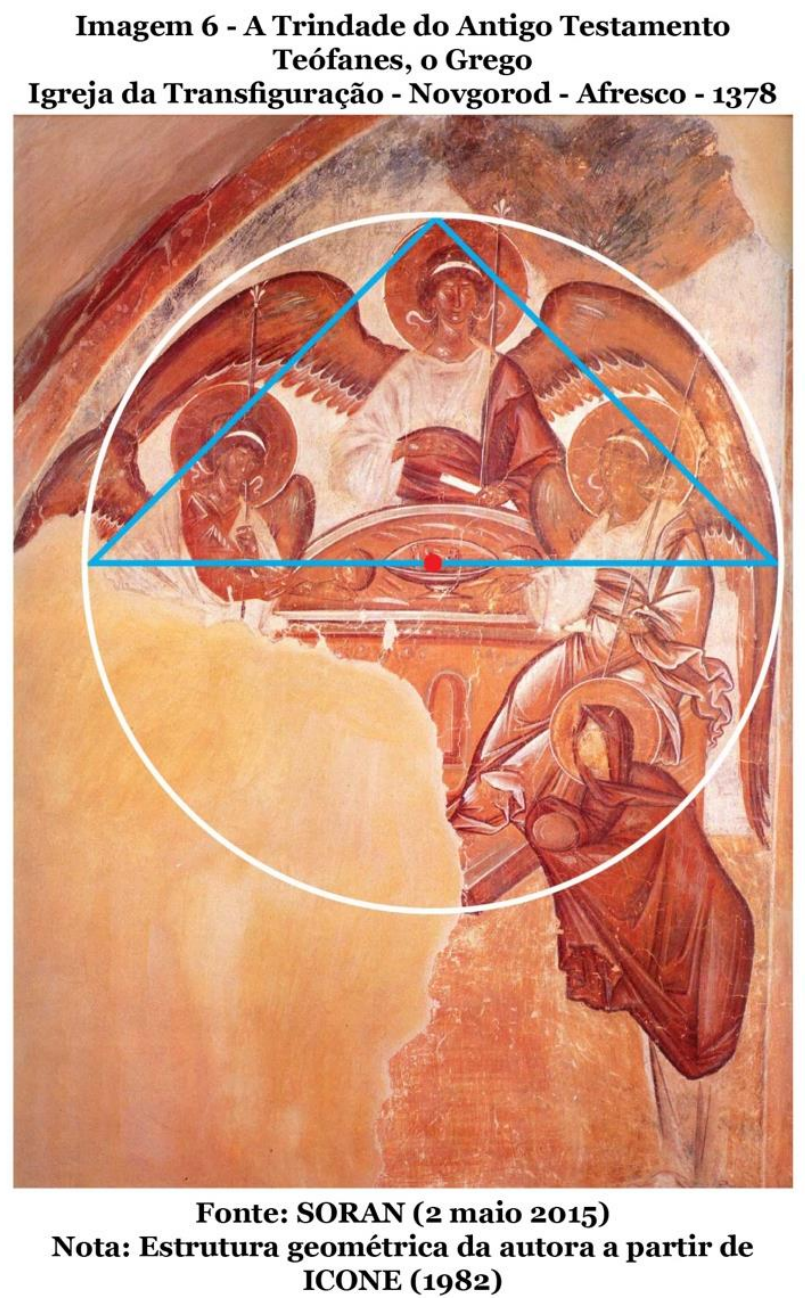

\subsection{O Concílio Vaticano II segundo Cláudio Pastro}

Pastro viveu em uma época em que a Igreja ainda permanecia sob as considerações feitas pelo Concílio de Trento ${ }^{14}$ mas, na sua adolescência, conheceu as reformas previstas por um evento que foi considerado o novo Pentecostes da Igreja: o Concílio Ecumênico Vaticano II.

O Concílio é uma reunião que tem caráter de cunho religioso. Do Concílio de Trento, que precisou rever a doutrina da Igreja por causa dos questionamentos protestantes

${ }^{13}$ L’intera composizione è contenuta in un triangulo, la parte superiore, i tre Angeli seduti al tavolo, forma un cerchio. Gli Angeli hanno in mano dei bastoni, mentre quello al centro nella sinistra tiene anche una pergamena; questo dettaglio è proprio della raffigurazione di Cristo Emanuele. (ICONE, 1982, p. 14)

${ }_{14}$ O Concílio Ecumênico de Trento foi convocado pelo Papa Paulo III, em 1542 e teve início em 1545. A Reforma protestante iniciada por Lutero expandia-se pela Europa e a Igreja Católica precisava rever sua doutrina. A promulgação das decisões tomadas, tornaram-se públicas somente em 1563, ou seja, o Concílio demorou 18 anos devido a várias interrupções e algumas delas ocorridas por constantes guerras. 
emergentes, ao Concílio Ecumênico Vaticano II, passaram-se quase 400 anos. Quando João XXIII assumiu o papado, em 1958, rapidamente convocou a Igreja a esse evento. Nenhuma questão urgente parecia ameaçar a Igreja Católica e ela seguia confiante de sua autoridade apesar das duas guerras que abalaram a primeira metade do século XX. Aparentemente, portanto, para muitos, o convite do Papa João XXIII seria só para reafirmar a centralidade e verdade da Igreja. Porém, esse seria um concílio para "[...] a iluminação, a edificação e a alegria de todos os cristãos [...]" (BELLITTO, 2016, p. 174) sem exceção, incluindo clero e leigos, assim como cristãos de outras confissões religiosas. O que aconteceu, na verdade, foi um Concílio pastoral que provocou uma verdadeira revolução copernicana na Igreja, abrindo-a para o diálogo com o mundo contemporâneo a partir da redescoberta de Jesus Cristo.

O que significa ser Pastro um artista pós-Conciliar? Qual a novidade proposta pelo Vaticano II que deu novos ares à liturgia e às artes na Igreja Católica?

Uma volta às fontes - Ad fonts. Esse era o leitmotiv que se ouvia antes, durante e após o Concílio Ecumênico Vaticano II, na década de 1960.

(...) Ao mesmo tempo que a Igreja parecia fechar-se sobre si mesma, em pleno final do século XIX, movimentos internos e intensos, como o surgimento de congregações religiosas de cunho educativo e social, a afirmação de um monarquismo profundo e os movimentos bíblico-teológicos, mais o movimento litúrgico da primeira metade do século XX começavam a exigir "uma volta às fontes". (PASTRO, 2001, p. 12).

O Cristo voltara a tornar-se a presença e o centro de toda a Igreja.

A Palavra era redescoberta e deveria questionar e plasmar a vida do cristão e da comunidade.

[...] A liturgia passou a ser, como conceito e realidade, o próprio Mistério Pascal do Cristo perpetuado na ação da Igreja. [...] Liturgicamente a assembleia cristã é convocada pelo próprio Cristo para celebrá-lo e quem preside essa ação eclesial é o Cristo. (PASTRO, 2001, p. 13).

Os cristãos reunidos ao redor de um só altar e o Mistério Pascal como centro da liturgia representaram o retorno aos primórdios do cristianismo, ao frescor da comunhão apostólica. Essa novidade trouxe, inclusive, o retorno à leitura dos Padres da Igreja.

A arte que brotou dessa abertura da Igreja foi essencialmente uma arte mistagógica, ou seja, que conduz ao centro da fé cristã. Na Abadia Nossa Senhora da Paz ${ }^{15}$, Pastro teve

\footnotetext{
15 O Mosteiro Nossa Senhora da Paz está situado em Itapecerica da Serra, SP. Foi fundado a partir da Abadia de Santa Maria, cuja instauração deu-se em 1911. Para o início da nova fundação vieram 9 monjas no ano de 1974 .
} 
contato com a leitura de teólogos que fizeram parte desse movimento de renovação. Foi a terra fértil que o recebeu e o educou. Madre Dorotéia Rondon Amarante (1916-2015) ${ }^{16}$, a primeira abadessa desse Mosteiro, forneceu-lhe grandes conhecimentos em arte, liturgia e vida eclesial.

\subsection{As estruturas geométricas}

A geometria presente na obra de Teófanes segue a base estrutural da composição de diversos ícones bizantinos, sobretudo dos grandes mestres. São estruturas escondidas, cujos segredos, afirma V. N. Lazarev (apud SENDLER, 1995, p.84, tradução nossa), não chegaram até nós, mas "[...] sob os afrescos foram descobertos traçados de linhas geométricas das quais o pintor se servia para organizar a superfície e executar livremente seu desenho"17.

Segundo Sendler (1995, p. 85), “as teorias das proporções do mundo greco-bizantino eram bem conhecidas na Rússia da Idade Média”, sendo as figuras mais utilizadas “[...] o triângulo, a cruz, o reticulado e o círculo” (SENDLER 1995, p. 87, tradução nossa) ${ }^{18}$. Segundo o autor, o triângulo, “[...] apoiado solidamente em sua base, em uma posição de equilíbrio: satisfaz tanto os olhos como o espírito. É utilizado também na pintura ocidental, sobretudo nas numerosas 'maternidades”' (SENDLER 1995, p. 87, tradução nossa) ${ }^{19}$. Pastro (2010, p. 42-43) sintetiza da seguinte maneira o significado de outras três figuras:

A cruz: surge do encontro de círculos. Identificação da união dos opostos, um novo centro. O quadrado: é a materialização do espaço. A terra é o lugar dessas manifestações. Indica também limites (para frente, para trás, para a direita, para a esquerda).

O círculo: sinal de perfeição, harmonia, unidade. Quem dessa forma participa, integra-se ao centro, encontra a paz e harmonia. (PASTRO, 2010, p. 42-43).

A partir dessas estruturas, as figuras e os objetos ocupam seu lugar na composição final da obra e esse lugar, em geral, está relacionado à importância e ao significado de cada figura ou objeto representado. Elas estão presentes nas obras de Rublëv e de Pastro e cooperam para o sentido teológico da obra.

\footnotetext{
${ }^{16}$ Madre Dorotéia foi a primeira prioresa designada para a fundação do novo Mosteiro da Paz. Em 21 de julho de 1974 houve a cerimônia de bênção do Mosteiro para início do louvor divino. Em 9 de setembro de 1983, a bênção Abacial de Madre Dorotéia Rondon Amarante. A atual Abadessa do Mosteiro Nossa Senhora da Paz é Madre Martha Lúcia Ribeiro Teixeira, osb.

${ }^{17}[. .$.$] sotto gli affreschi si sono scoperti dei tracciati di linee geometriche dei quali il pittore si serviva per$ organizzare le superfici ed eseguire quindi liberamente il suo disegno. (Lazarev apud SENDLER, 1995, p.84).

18 [...] il triangolo, la croce, il reticolato ed il cerchio. (SENDLER 1995, p. 87).

${ }_{19}$ [...] appoggia solidamente sulla base, in una posizione di equilibrio: soddisfa l'occhio come lo spirito. $\grave{E}$ utilizzato anche nella pittura occidentale, soprattutto nelle numerose "maternità".(SENDLER 1995, p. 87).
} 
A visualização das imagens com a sobreposição das formas geométricas evidencia a composição das obras (Imagem 7). A cruz latina (com a haste vertical maior que a horizontal) é formada a partir do encontro das linhas que dividem as pinturas em duas partes iguais com a linha superior do quadrado. Esta última figura, juntamente com o círculo, reforça o conjunto, a unidade e o movimento circular dos três anjos. Enquanto "o círculo é símbolo do divino, o quadrado é símbolo do humano, da terra, de uma humanidade que pode chegar à perfeição" (LICARI, 2013, p. 68). Para Burkhardt (apud MEIER, 2019, p. 299) “a cruz [...] é o elemento mediador entre o círculo do Céu e o quadrado da terra; e a perspectiva cristã enfatizará, antes de tudo, o papel do Divino Mediador”. O carvalho de Mambré, representado pela árvore ao fundo, reforça a simbologia da cruz, recorda a paixão de Cristo.

Há um outro elemento estrutural importante para a leitura da obra: o triângulo (Imagem 8). No caso específico das pinturas analisadas, esta figura aparece com os três lados iguais.

O triângulo equilátero significa a unidade na multiplicidade, a igualdade na distinção. É símbolo por excelência da Trindade [...]. O triângulo "com o vértice para o alto (cabeça de Cristo), indica subida, ascensão; o segundo, com o vértice para baixo (cálice sobre o altar), indica descida, encarnação. (LICARI, 2013, p. 68).

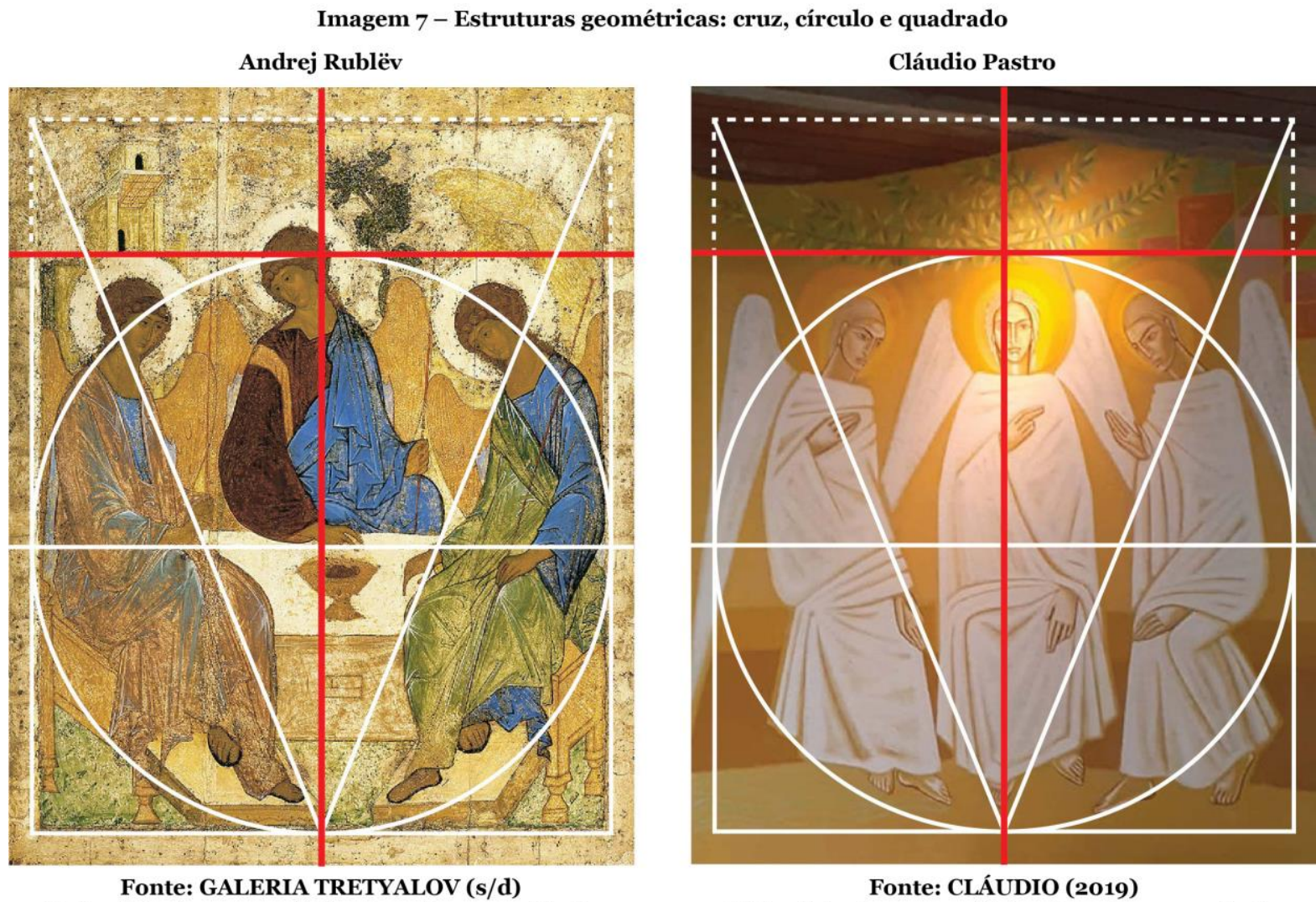

Nota: Estrutura geométrica da autora a partir de SENDLER (1995)

Nota: Estrutura geométrica da autora a partir de SENDLER (1995) 
Na interseção das linhas dos triângulos pode-se traçar uma linha horizontal que divide o quadro em duas metades. A metade superior corresponde ao mundo celeste e a inferior ao mundo terrestre. Eis uma breve síntese (Quadro 1) comparativa entre as duas partes que compõem as obras:

\section{Quadro 1: Síntese comparativa}

\begin{tabular}{|c|c|c|}
\hline Mundo celeste & Andrej Rublëv & Cláudio Pastro \\
\hline & Casa - Tenda dos Patriarcas & Casa - Capela e o fiel \\
\hline & Árvore - Carvalho - A Cruz & Árvore - Carvalho - A Cruz \\
\hline & Montanha & ------------------------------ \\
\hline & $---------------------------~$ & Jerusalém Celeste - Casa do Pai \\
\hline
\end{tabular}

\begin{tabular}{|c|c|c|}
\hline Mundo terrestre & Andrej Rublëv & Cláudio Pastro \\
\hline & Mesa com o cálice & Pequeno altar do tabernáculo \\
\hline & Retângulo - relicário dos mártires & ------------------------- \\
\hline & --------------- & Abrão e Sara - o fiel \\
\hline
\end{tabular}

Fonte: autora, 2020

Imagem 8 - Estruturas geométricas: triângulos

Andrej Rublëv

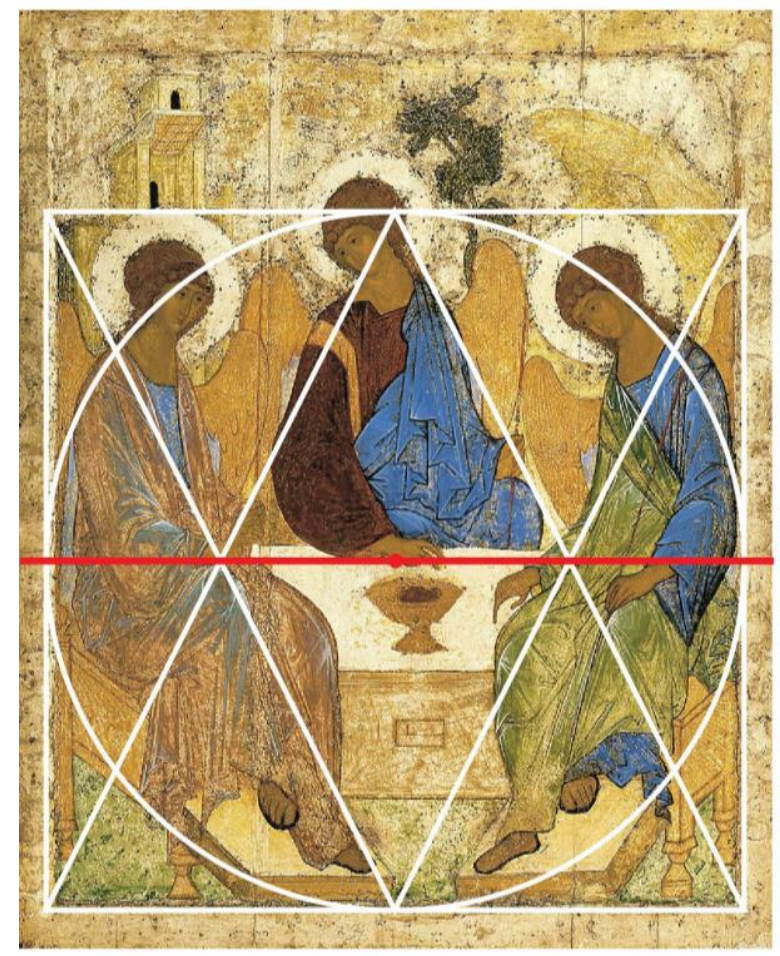

Fonte: GALERIA TRETYALOV (s/d)

Nota: Estrutura geométrica da autora a partir de SENDLER (1995)

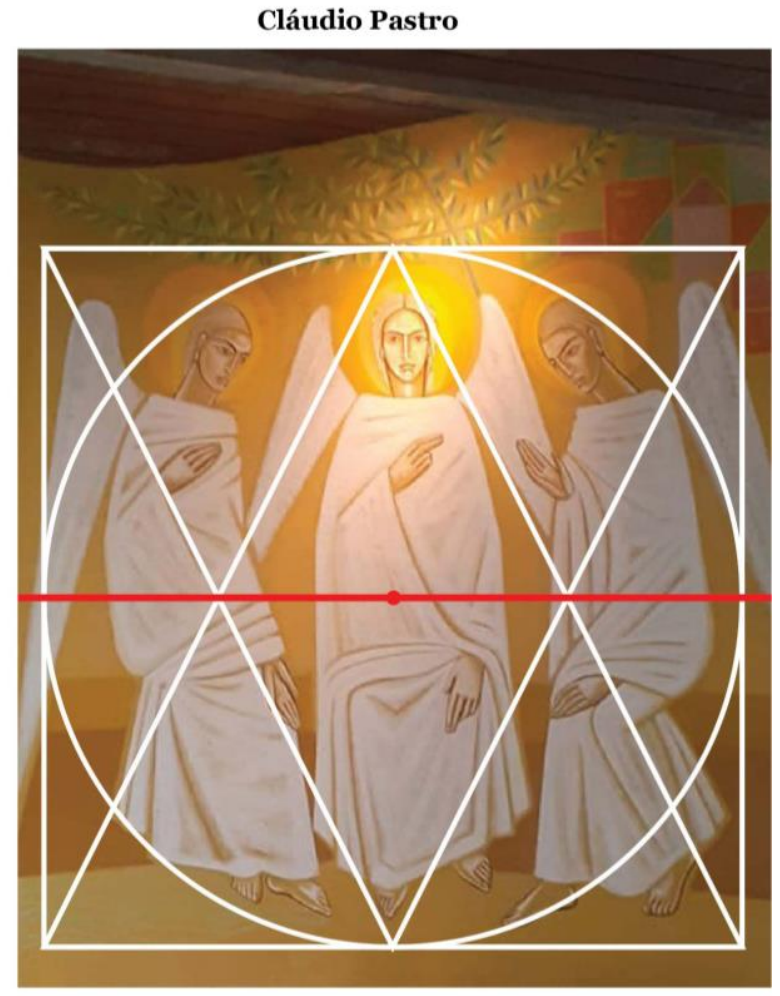

Fonte: CLÁUDIO (2019)

Nota: Estrutura geométrica da autora a partir de SENDLER (1995)

\subsection{A iconografia e a iconologia}

Na representação da Santíssima Trindade de autoria de Rublëv, quanto à distinção das três pessoas, entre as muitas hipóteses dos estudiosos para captar na pintura a 
simbologia desejada pelo artista, Gharib (1997) escreve: "Anjo da esquerda = PAI, Anjo central $=$ FILHO e Anjo da direita = ESPÍRITO SANTO".

Na obra de Pastro (PASTRO, 2008) o relato é claro: o Anjo da direita é o PAI, o Anjo do centro é o Filho e o Anjo da esquerda é o Espírito Santo.

$\mathrm{Na}$ análise pré-iconográfica comparativa, seguindo o método de Panofsky (2017), elementos análogos estão presentes nas pinturas de Rublëv e Pastro (Imagem 9): três homens alados, sentados, aureolados, uma estrutura arquitetônica, uma árvore ao fundo e um ponto importante a ser destacado que é a fisionomia das figuras que não se alteram. Em cada uma das obras, e de acordo com a expressão plástica de cada artista, elas se repetem, sem uma preocupação naturalista de retratar, por meio da face, quem é quem. Pode-se verificar que a identificação das pessoas da Trindade ocorre pelo movimento e pela postura dos corpos, pela inclinação da cabeça, pelos olhares, pelos pés e, sobretudo, pelas mãos que são o instrumento para revelar a missão de cada pessoa trinitária e a missão dada a cada um de nós. Como definição teológica do corpo na arte sacra, Pastro esclarece: "o corpo é a melhor obra. Não tem obra mais importante, pois sem o corpo não tem o espírito" (TORRES, 2007, p. 177). Existem elementos presentes somente na pintura de Rublëv: montanha ao fundo, mesa com urna para relíquias, cálice, cordeiro, cajados, cores dos mantos diferenciadas e formas retangulares na parte inferior do quadro. Na obra de Pastro, há um elemento inexistente em Rublëv: um movimento de água no pé do anjo que está à esquerda.

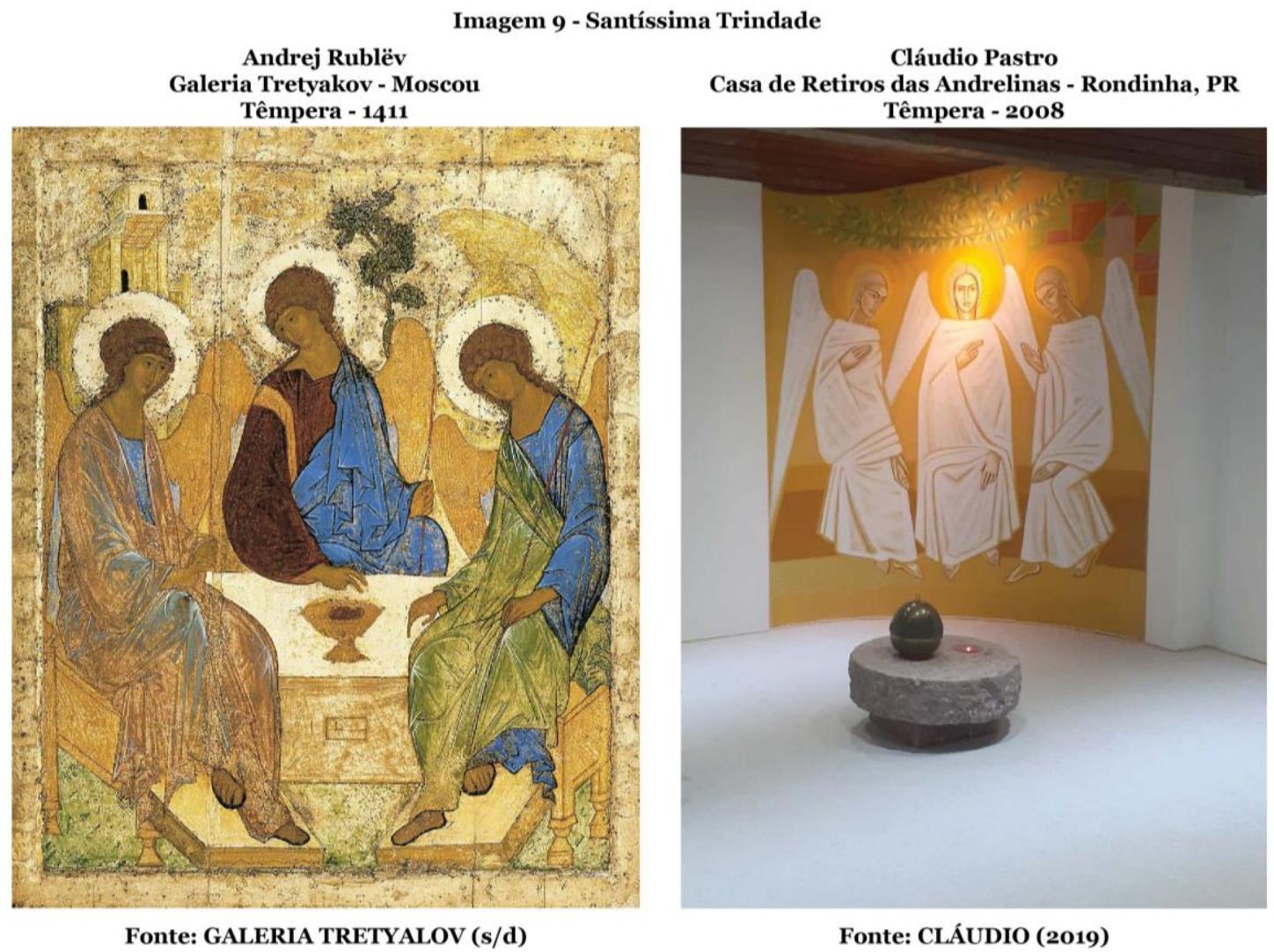

INTERAÇÕES, Belo Horizonte, Brasil, v. 15, n. 02, p. 270-293, jul./dez. 2020 - ISSN 1983-2478 
Os comensais ocupam três dos quatro lugares da mesa. Deixaram-no livre um. Este lugar vazio é a vocação humana: Deus criou o homem e o redimiu fazendo-o partícipe de sua vida. Este é o único acesso à comunidade trinitária: dizem-no as asas dos três anjos não deixando brecha em torno da mesa.

[...] Há um lugar, portanto, para cada um de nós no círculo de amor das três pessoas divinas. [...] Penetremos no hino de agradecimento que chamamos Eucaristia e que nos faz sentar no banquete de Deus Pai, Filho e Espírito Santo. (LICARI, 2013, p. 77-78).

Convidados a participar do banquete eucarístico da Trindade, realiza-se a nossa vocação de cristãos, assim como na liturgia, quando somos convocados a uma participação ativa e consciente. "A contemplação da Trindade [...] revela o sentido mais profundo da missão, descrita pelo Concílio Vaticano II como plano trinitário de fazer da comunidade divina e da comunidade humana uma só família” (LICARI, 2010, p.78).

Parece evidente que o que chama mais atenção nas pinturas Rublëv e de Pastro é a localização da mesa. Em Rublëv, ela faz parte da composição, da construção formal da obra. Cumpre seu papel como um dos elementos significativos para a compreensão da totalidade do trabalho do iconógrafo. Sobre ela estão o cálice e o Cordeiro, símbolos eucarísticos, e ainda, porque ela é parte intrínseca da composição, divide, com sua horizontalidade, o céu da terra.

Pastro subtrai a mesa do espaço pictórico para ocupar um lugar no espaço da Capela. Essa mesa é o sacrário que guarda as reservas eucarísticas, ou seja, o próprio Jesus. É uma presença. O espaço não está vazio. É convidativo e participativo, é a “ideia da autocomunicação em amor [...]" (WERBICK, 2001, p. 452). "O amor mútuo permaneceria ‘egoísmo a dois', se não desejasse que a alegria e a bem-aventurança [...] fossem partilhadas por um terceiro, por um “coamado [...]”" (WERBICK, 2001, p. 453).

Em que consiste a necessidade da tri-unidade?

[...] 'no amor mútuo, também no mais ardente, nada [...] é mais raro, no entanto também nada é mais grandioso do que a vontade de que aquele que ama ao máximo e que ama a ti ao máximo também ame um outro do mesmo modo. Portanto, a prova para o amor perfeito é o desejo que o amor experimentado seja transmitido a outros. (RICARDO DE SÃO VÍTOR, De Trin. III 11 apud WERBICK, 2001, p. 452-453).

Como artista do século XX, Pastro identifica em sua obra aspectos da tradição oriental que são essenciais para se falar em arte sacra. Traz, por meio dessa tradição, o que significa ser um artista na contemporaneidade lidando com conceitos como a beleza e o sagrado, tão relativizados e colocados como critérios subjetivos de prazer. 
A verdadeira arte sacra, caminha com dois pés, um pé na tradição, nas raízes do cristianismo e o outro pé no hoje.

[...] o trabalho de arte sacra é a transposição daquilo que está escrito alfabeticamente para a forma e cor. Então é a mesma linguagem do evangelho em ordem alfabética transcrita para a forma e cor. É uma continuidade, você percebe, não tem o supérfluo, eu não estou interessado na paisagem, não estou interessado que o corpo esteja perfeito, nada, estou interessado que o espírito passe nestas poucas linhas. (PASTRO apud TORRES, 2007, p. 178-180).

O relato deixado por Pastro (2008), como complemento de entendimento à sua obra, exibe aspectos singulares da experiência religiosa do artista. Como afirmamos acima, os cânones da pintura sacra não esgotam ou comprimem a criatividade de quem a executa, o artista não é um mero executante, mas coloca sua disponibilidade e seu talento para "ser testemunha de um outro mundo presente entre nós" (PASTRO, 2010, p. 127). A liberdade alicerçada na Traditio artística da Igreja, permite ao artista sacro valer-se de sua imperiosa necessidade de criar, sem prejuízo da tradição.

Segue o texto na íntegra:

O painel é feito com pigmentos coloridos, água e cola branca na técnica "a têmpera" ou "a fresco pompeniano" (sic).

O ícone em sua composição repete a imagem da Tradição baseada em Gn 18,1-15. Os hospedeiros não estão presentes na cena nem a mesa da refeição, pois, Abraão e Sara "estão em cada um de nós" e a Eucaristia (o pequeno altar do Tabernáculo), a refeição que nos une, está logo à frente.

Os Anjos hóspedes estão sentados na "tenda de Abraão", isto é, a Capela em si ou "a morada" que cada um de nós é. O Anjo da direita corresponde a Deus-Pai. No olhar infinito dos seus desígnios Ele é completamente voltado para o Filho (arquétipo de toda a criação) e, assim, a cada um de nós, filho no seu Filho.

Ao alto, a Jerusalém celeste, com muitas moradas é a Casa do Pai, nossa única morada, a eternidade para onde peregrinamos. O Anjo do centro corresponde ao Filho. É o único que nos encara: "Quem me vê, vê o Pai”. É o Anjo da revelação, a razão do Pai. Sua mão direita está voltada para o Pai e seus dois dedos levantados indica-nos as suas duas naturezas divina e humana - e ser Ele a Segunda Pessoa da Trindade.

Sua mão esquerda, para baixo, quer nos dizer que Ele está aqui, presente em nosso meio, na refeição eucarística. Às suas costas está a Árvore da Vida, a Cruz, com a qual ele nos abriu o Paraíso. O Anjo da esquerda corresponde ao Espírito. Está completamente voltado para o Filho e o Pai e sua mão esquerda, aberta, apresenta-nos e nos convida a entrar nessa relação amorosa, lá onde nossa vida ganha sentido. De seus pés saem "rios de água viva" que brotam desse Espírito de Amor e de Sabedoria.

O ícone é a Palavra de Deus, não em be-a-bá mas, em formas e cores, como nós, "à imagem e semelhança”, mistério invisível no visível da imagem. O ícone é o prolongamento do Mistério da Encarnação em nossa humanidade. (PASTRO, 2008).

Para Pastro, a inclusão de cada um de nós no mistério de comunhão da Trindade se dá por meio dos personagens ausentes: Sara e Abraão. Para a nossa esterilidade existe uma promessa tão grande ou até maior que as estrelas do céu e, na vida eterna, uma morada na Casa do Pai, na Jerusalém Celeste. 


\section{CONSIDERAÇÕES FINAIS}

O colóquio entre arte e teologia aqui proposto, com as análises feitas nas pinturas de Rublëv e Pastro, dão uma resposta às seguintes perguntas mencionadas ao longo do texto: a maneira como estão representadas as três pessoas, nas obras de Rublëv e de Pastro, nos comunicam a dimensão da reflexão teológica que esse tema traz? Uma pintura pode traduzir em traços e cores a comunhão, a partilha, a unidade e perfeita integração do tema da Trindade tanto quanto um texto escrito?

Como afirmamos, o ícone é a Palavra pintada e a fidelidade às Escrituras é a sua principal fonte de inspiração. O ícone está entre o mundo material e o mundo espiritual.

Em Rublëv e Pastro essas questões já estão comunicadas no conjunto de suas obras e também nas pinturas analisadas neste estudo.

O artista sacro sabe que seu trabalho está a serviço da fé, mas isso não interfere na sua criação, pelo contrário, potencializa seu talento e a sua liberdade. Seu estado de vida, de oração e fidelidade à tradição, converte sua obra em objeto de veneração. Isso faz que seus trabalhos não sejam objetos de arte, mas se transformem em objetos de culto.

O que a Sagrada Escritura exprime com a palavra, o ícone proclama com as cores e traços. A imagem é o reflexo do protótipo, do modelo original. Rublëv e Pastro não esgotam a visão do tema da Trindade, mas traduzem em suas representações pictóricas uma questão importante que a Doutrina da Trindade nos revela: a comunhão, a circularidade e o mistério de três em um. Os ícones da Trindade de Rublëv e de Pastro transmitem a mensagem de que Deus é a comunhão, é o amor, conforme lemos em I João 4,8.16.

\section{REFERÊNCIAS}

ANGE, Daniel. L’abbraccio di fuogo: l’icona dela Trinità di Rublëv. Milão: Àncora Editrice, 2014.

BEZANÇON, Jean-Noël. Representar a Trindade. In BEZANÇON, Jean-Noël. Deus não é solitário: a Trindade na vida dos cristãos. Trad. Pe. Maurício Ruffier, SJ. São Paulo: Edições Loyola, 2003.

BELLITTO, Christopher M. História dos 21 Concílios da Igreja: de Niceia ao Vaticano II. Trad. de Cláudio Queiroz de Godoy. 2. ed. São Paulo: Edições Loyola, 2016.

BÍBLIA DE JERUSALÉM. São Paulo: Edições Paulinas, 1981. 
BINGEMER, Maria Clara L.; FELLER, Vítor Galdino. A aventura de pensar e falar sobre o Deus de nossa fé. In BINGEMER, Maria Clara L.; FELLER, Vítor Galdino. Deus

Trindade: a vida no coração do mundo. São Paulo: Paulinas; Valencia: Siquem, 2003.

CAMARGO, Patrícia de. In: CAMARGO, Patrícia de. Turomaquia. 31 jan.2017. A Virgem que se abre - um tríptico da Idade Média. Paris: Museu Cluny, 1400. Disponível em: https://www.turomaquia.com/a-virgem-que-se-abre-um-triptico-privado-da-idademedia/. Acesso em: 08 out. 2020.

CATECISMO DA IGREJA CATÓLICA. 3. ed. São Paulo: Editora Vozes, Paulinas, Loyola, Ave-Maria, 1993.

CLÁUDIO, Frei Everton Ramos, O.carm. Santíssima Trindade de Cláudio Pastro. Casa de Retiros das Andrelinas: Paraná, Rondinha, 2019.

CONCÍLIO VATICANO II. Constituição sobre a Sagrada Liturgia Sacrosanctum Concilium. $11^{\text {a }}$ ed. São Paulo: Edições Paulinas, 2011.

COURTAULD GALLERY. Sandro Botticelli: Trinity with Saints (1491-94). London: 2016. Disponível em https://courtauld.ac.uk/event/lunchtime-talk-sandro-botticelli-trinitywith-saints-021116. Acesso em: 29 dez. 2019.

DOCUMENTOS DO CONCÍLIO VATICANO II. Disponível em: <http://www.vatican.va/archive/hist_councils/ii_vatican_council/index_po.htm>. Acesso em 17 dez. 2019.

DONADEO, Ir. Maria. Os ícones: imagens do invisível. São Paulo: Edições Paulinas, 1996.

FLORENSKIJ, P. Le porte regali: suggio sul'icona. Milão: Adelhi Edizioni, 1977.

FORTE, B. A Trindade como história. São Paulo: Paulinas, 1987.

GALERIA TRETYALOV. Andrej Rublëv: a Santíssima Trindade. Moscou, s/d.

Disponível em: https://www.tretyakovgallery.ru/pt/. Acesso em: 8 out. 2020.

GHARIB, G. Os Ícones de Cristo: História e Culto. São Paulo: Paulus Editora, 1997.

GRANDE SÍNODO DE MOSCOU. Disponível em:

https://www.ecclesia.org.br/biblioteca/iconografia/a-trindade-santissima-nossodeus.htm. Acesso em: 17 dez. 2019.

ICONE: Teofane Il Greco. Testi di Adam Russak e Coop. Edit. "La Casa di Matriona". Milão: Cooperativa Editoriale "La Casa di Matriona", 1982.

LICARI, Saverio. O Ícone: uma escola de oração. 2 ed. São Paulo: Edições Loyola, 2013.

MEIER, Christiane. Iconografia da Santíssima Trindade: uma historiografia imagética. Embu-Guaçu, SP: Lumen et Virtus, 2019. 
MEIRA, André Luiz Bordignon. A Trindade como relacionamento misericordioso na relação humana, a partir de Von Balthasar. Revista Eletrônica Espaço Teológico. ISSN 2177-952x, [S.1.], v. 11, n. 19, p. 37-45, set. 2017. ISSN 2177-952X. Disponível em: <https://revistas.pucsp.br/reveleteo/article/view/34410>. Acesso em: 03 jun. 2020.

MONDONI, Danilo. O cristianismo na antiguidade. São Paulo: Edições Loyola, 2014.

MOSTEIRO DE SÃO BENTO DO RIO DE JANEIRO. Oblatos seculares. s/d. Disponível em: https://www.mosteirodesaobentorio.org.br/vocacoes/oblatos-seculares\#. Acesso em 23 mar. 2020.

MUSEU ARQUIDIOCESANO DE SANTARÉM. Santíssima Trindade. Oficina portuguesa (Lisboa), pintura anônima segundo gravura da obra de Guido Reni (1575-1642) para a Igreja da Santíssima Trindade dei Pellegrini, em Roma; óleo sobre tela século XVIII (primeira metade); Paróquia de São Nicolau de Santarém: s/d. Disponível em: http://www.museudiocesanodesantarem.pt/portfolio/santissima-trindade-2/. Acesso em: 9 out. 2020 .

PANOFSKY, E. Significado nas artes visuais. Trad. Maria Clara F. Kneese e J. Guinsburg. 4 ed. São Paulo: Editora Perspectiva, 2017.

PASSARELli, G. O ícone da Trindade. São Paulo: Ave Maria Edições, 1996.

PASTRO, Cláudio. C. Pastro: arte sacra. São Paulo: Edições Paulinas, 2001.

PASTRO, Cláudio. Texto de Cláudio Pastro a respeito da obra para a Capela da Casa de Retiros das Andrelinas. Acervo da Casa de Retiros das Andrelinas. Brasil, Paraná, 2008.

PASTRO, Cláudio. Arte no cristianismo: fundamentos, linguagem e espaço. São Paulo: Paulus Editora, 2010.

SENDLER, Egon. L'icona, imagine dell'invisibile: elementi di teologia, estética e técnica. 5 ed. Milano: Edizioni San Paolo, 1995.

SORAN, Ioan. A Reprezentări triandrice ale Sfintei Treimi în pictură, mozaic șisculptură. In Ioansoran Word Press Page. 09 março 2015.

Disponível em: https://ioansoran.wordpress.com/2015/o3/o9/reprezentari-ale-sfinteitreimi-in-arta-3/. Acesso em: 24 ago. 2020.

SORAN, Ioan. Reprezentarea Sfintei Treimi în spațiul răsăritean. In Word Press Page. o2 maio 2015. Disponível em:

https://ioansoran.wordpress.com/2015/05/02/reprezentari-ale-sfintei-treimi-in-arta-5/. Acesso em: 24 ago. 2020.

ŠPIDLÍK, Tomás; RUPNIK, Marko Ivan. La fede secondo le ícone. Roma: Lipa, 2000.

TORRES, Marília M. de M. S. O Cristo do Terceiro Milênio: a visão plástica da arte sacra atual de Cláudio Pastro. Dissertação de Mestrado em Artes. Universidade Estadual Paulista Júlio de Mesquita Filho, Instituto de Artes. São Paulo, 2007.

WERBICK, Jürgen. Doutrina da Trindade. In: SCHNEIDER, Theodor (org.). Manual de Dogmática. vol. 2. Trad. Ilson Kayser. Petrópolis: Editora Vozes, 2001, p. 429-511. 
ŽAK, Lubomir. A Trindade como mistério central da fé cristã. In ŽAK, Lubomir. Trindade e imagem: aspectos da teologia mística de Vladimir Losski. Org. Márcio Luis Fernandes. São Paulo: Ave Maria Edições, 2012.

Recebido em: 30-12-2019 Aprovado em: 09-09-2020 